MAY 26 '94 14:47 MESG CNTR 586-2866

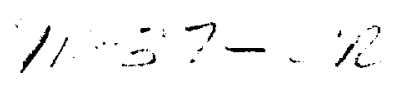

P.2

NASA-CR-202082

\title{
REDEBIGN AND TEST OF AN SSME TURBOPUMP FOR THE LARGE THAOAT MAIN COMBUSTION CHAMBER
}

\author{
K. J. Lundo, O. A. Leo, A. H. Eastland and L. Rojas \\ Rockwoll Intornational Corporation \\ Rockeldyne Dlvision \\ Canoga Park, Calkomia
}

\begin{abstract}
Abntrnes
The prebumer oxidizer turbopump for the Spece Shuttle Main Englne (SSME) was successtully redesloned for use whth the Lange Throat Main combustion Chamber (LTMCC) and tested in air utilizing rapid protolyping. The redesign Increasos the SSME's operating range with the curren Main Combustion Chamber (MCC) while achioving full operational range with the LTMCC. The use of rapid prototyping and alr testing to validate the redesion demonstrated the ability to design, fabricato, and test designe rapldy and at a very low cost.
\end{abstract}

\section{Nomsnclature}

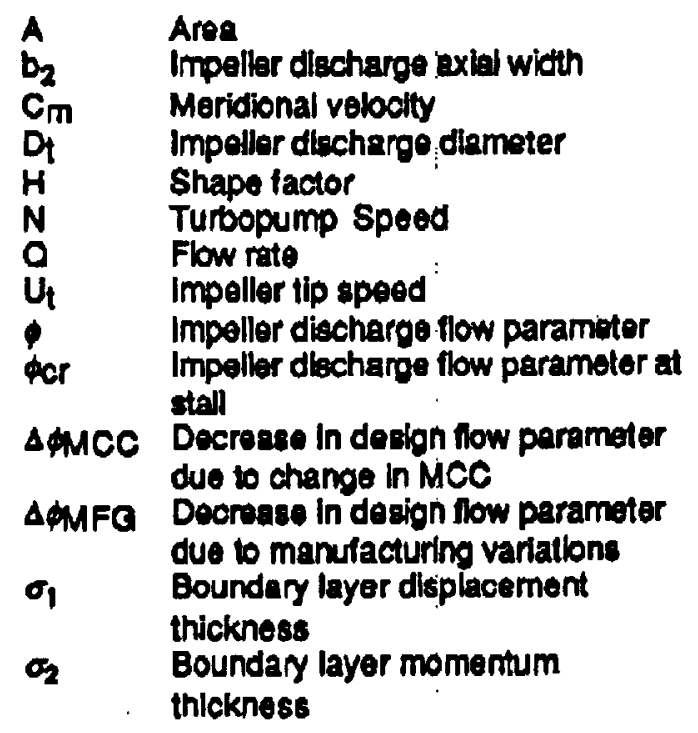

\section{Backaround}

The SSME utlikes a staged combustion cycle in order to maximize the engine's specilit impulse (Figure 1). A proburner provides high temperature, high pressure lluid to ditwe the
High Proseure Fuel and High Proseure Oxidzer Turbopumps (HPFTP and HPOTP respectlvely). The oxidizer for the probumers is provided by a proburner pump (PBP) which increases the HPOTP discharge pressure to the probumer Inlet prossure. On the SSME, the proburner pump is allached to the shatt of the HPOTP (Floure 2). Therefore, the PBP flow rate is linked to the HPFTP and HPOTP power requirements and its speed is determined by the HPOTP.

The throat area of the curremt Phase II MCC is beling enlaroed to reduce the SSME's chamber proseure while maintalning its thrust capability. increasing the throat area results in lower turbomachinery discharge pressures while maintaining the current flow rate requirements. Therefore, the HPFTP and HPOTP operate at lower speeds and require less power with the LTMCC than with the Phase II MCC. This results In lower PBP flow rates and lower speeds for the same engine thrust lovel.

During the shutile ascont, each SSME is throttled from $65 \%$ to $104 \%$ of the deslgned thrust level. While hot fire tosting of a SSME engine with a LTMCC, a bi-stable operation occurred at a power level of $67 \%$. Bl-stabilty results in rapld ohanges in the chamber pressure (Flgure 3); has been observed with the current MCC at power levels of $65 \%$; and has been aftrlbuted to a preburner pump stall condtition. Bl-stablity occure when the MCC pressure rapidly oscillatos. The source of this oscillation is stalling of the PBP.

When the probumer pump stalls, ths diacharge preseure suddonly decroases. Thls decreases the power to the high pressure turbopumps which decreases the combustion chamber pressure. Attempting 10 malntain the thrust requlrements, the SSME controllor (which comrole the engine valve positlons) Increases the preburner flow rate to Increase the high pressure turbopump's Input power and diacharge pressure (Figure 4). The increase in 
PBP flow rate causen the PBP to unstall which rapldy Incraseses the PBP discharo pressure; the hloh proesure turbopump power, and the chamber pressure. The ohamber pressure Increases beyond the desired value and the controller respond by decreasing the PBP llow rte. This causes the PBP to resume a stalled condition. This cycle is known as bi-stabiliy.

Ar testing of several preburnor turbopumps in tho enty 1980' demonotrated that the anse of the turbopump stall is the preburner pump difluser. Therutore, a tack to ellminate the etain over the range of the LTMCC by redesigning the probumer pump diffuser was Inilated.

\section{Bederion objetues}

The design objectlves were to operate the prebumer pump it the $83 \%$ power lovel for the LTMCC while maintaining the curren tutbopump operating characterletics at the $109 \%$ power lovel for the Phese II MCC. The 63\% powar level objective is bases on the requirement that the SSME englne operate on test stand whth $2 \%$ power lovel margin from the minimum mission power level of 65\%. In addition, the SSME engine must be able to operale at $109 \%$ power level in the case of an engine shut-down during ascent.

\section{Anfivtical Approneh}

Although the vaned difluser had been ldentifled as the soupce of stall, the stall mechenism had not been determined. Two posslble sources of glall were conskdered: 1) loading edoe stall and 2) stall due to boundary layor soparation. Both atell mochanisms were analyzed and used to determine new diffuser deslghs.

The leading odge stall model used was doveloped tor vaned dffuser and anchoped to exporimental dala for conleal difuser. "Tho Incidence angle at which dall occure is a tunction of the leading edoe blade angle (Fioure 5). Caloulating the diffuser incldence anglo requires knowing the impoller discharge absolute flow angle, and datermining the effects of boundary layer blockage and blade blockage on the difuser Inlet llow area. Caleulation of these parametere is performed. with Rocketcyne's proprbtary centritugal pump poriormance code. Thls program was used to dodgn the officusers leading odoe blade anglo, Iniat blede hoight, and leading odge blede thickness. Nso, the effect of the iralling edge thlcknese and discharge blade helght on performance is determined with this code.

The second etoll mechanism wes analyzed using a potential flow mothod to prediet the voloctly protllo adfecent to the airfoll and a boundary layer code to doterming y boundary Lyer separtion hes occurred. 2,8 Since the PBP diffuar Includes an increase in axial lendth from the inlet to the dlecharge. a streamtube thlekness distribution was used to pertorm quasl 3.0 andyals. The boundary layer was deftnod as separated when the shape factor was greater than 2.4 af a distance lese than $90 \%$ of the blade aurace length. The shape factor is deilned as follows:

$$
H=\frac{\sigma_{1}}{\sigma_{2}}
$$

A vane geometry protlle code generated the vans desions and was rapidly analyzed with the potentlal flow code to determine the pressure distributlon and the boundary layer code to determine if the flow separated. Since the PBP performance and operating point where leading odge stall occure ls a tunction of the blade leading edge thicknoss, an tieration between the resulting vane geometry and the pertormance code was required.

\section{Redesian Reoulroments}

The SSME engine system model calculates the operating paramelers for the entlre engine system for each power lovol. This model was used to evaluate the impact on the preburner pump of Using the LTMCC. From the engine system model, it was determined that the prebumer pump muet operate at a lower impeller discharge flow parameter. The impelier dischares flow parameter is deflned as:

$$
\phi=\frac{C_{n}}{U_{1}}=\frac{Q}{A U_{l}}
$$

where $A=\pi D_{1} b_{2}$

$$
U_{1}=N D_{1}
$$

Therefore:

$$
\phi \propto \frac{g}{N}
$$


The operating requiremente at the $63 \%$ and $108 \%$ for both the current Phase II MCC and thio
LTMCC are listed in Table 1.

\begin{tabular}{|c|c|c|c|c|}
\hline & \multicolumn{2}{|c|}{ Phise | MCC } & \multicolumn{2}{c|}{ Large Throat MCC } \\
\cline { 2 - 5 } & $63 \%$ Thrust & $109 \%$ Thnust & $63 \%$ Thrust & $109 \%$ Thrust \\
\hline Q(GPM) & 291.3 & 699.0 & 270.2 & 657.2 \\
N (RPM) & 18,923 & 29,141 & 18,643 & 28,989 \\
& 0.058 & 0.090 & 0.054 & 0.085 \\
\hline
\end{tabular}

Table 1 - Operating Requlrements of the Prabumer Turbopump

This results in the following redestan requiremente:

\begin{tabular}{|c|c|c|c|}
\hline Power Level & Phase IIMCC & LTMCC & $\Delta 6$ \\
\hline $63 \%$ & 0.058 & 0.054 & 0.004 \\
$109 \%$ & 0.090 & 0.085 & 0.005 \\
\hline
\end{tabular}

Table 2 - Impeller Dischargo Flow Parameter,

In orter to achleve the design objectwes, the impelier tlow parameter af which ctall occurs (fer) must be decreased by 0.004 for the $63 \%$ powrer lovel, A value of 0.005 was used for the redesion to provide margln. Based on engine test data and prior air tost experience, an additlonal 0.005 decrease in por is required to account for manufacturing variations. Thus, the redeslon requirement is:

$$
\Delta \phi_{C R}=\Delta \phi_{M C C}+\Delta \phi_{M N O}=0.005+0.005=0.010 \text {. }
$$

\section{Basallne Imnaller Diffuser Deslan}

Two diffuser dosions were completed and tested for use with the baseline 5.0" dlameter impeiler. The diffuser Inlet geometry was designed using the perfomance analysis program. For the first diffuser redesign, the leading edee blade angle was decroased by $9^{\circ}$ and the inlet blade height was decreased umil tor was decreased by 0.010 . This resulted in a $0.218^{\prime \prime}$ Inlet blade helght compared to $0.250^{\circ}$ lor the baseline diffuser design. Then the potentfal flow and boundary layer codes were used to datermine the blade thickness proflle. The blade protile for the firet redeslon is thickar than the current diffuser dealon and the wrap angle b alightly larger (Figure 6). The pressure;(Figure 7) and shape factor distributions (Floure B) for $\Delta \phi$ or of 0.010 olve an attached boundary. layer on both the pressure and suction surfaces.

For the recond difluser design, the Inlet blade height was held at $0.250^{n}$ and the inlet biade angle was decroesed untli der was decreased by 0.010 . Again, the leading edge blade thicknes: and blade thickness distribution were Increased over the current diffuser desion (Floure 9 ). Similar to rodesign $\# 1$, the potential flow and boundary layor analysis codes wers used to obtain this blade protile. 


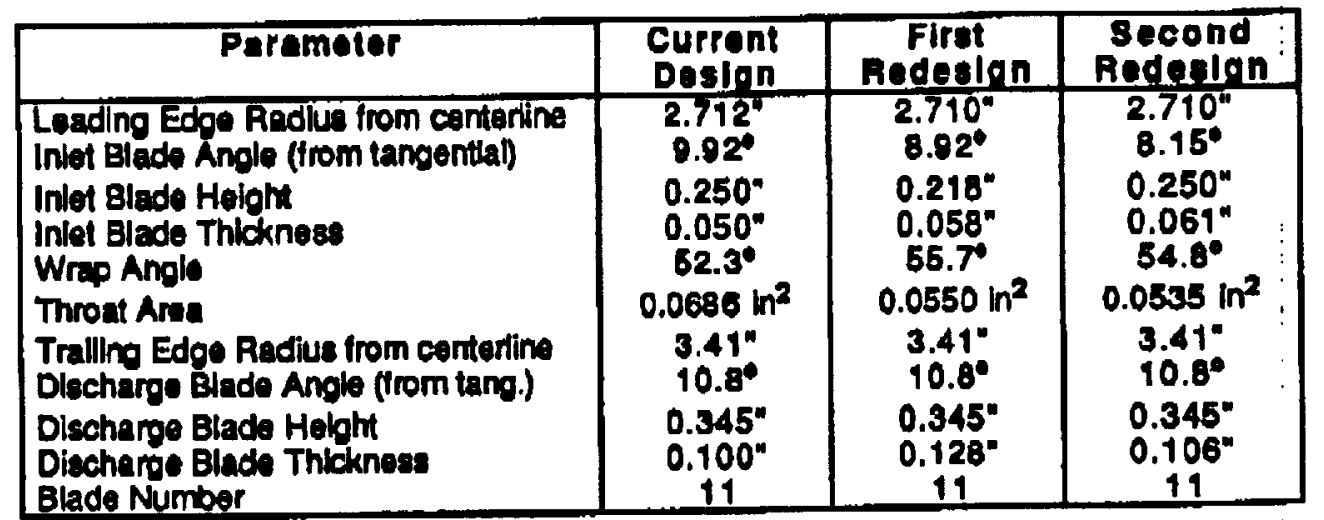

Table 3 - Probumor Turbopump Diffuser Deslgn Parameters

Increasing the operating range of the PBP requlred redestoning the diffuser with zero incidence at a lower (engine thrist level) than the baseline diffucer deslon (Floure 10). This causes an fncrease in incloonce at the higher thrust lovels; an increase in dituser presesure loss; and a lower pump discharge pressure. Thl was confirmod whth the pertormanos analysis code. Thus, the penalty of wide flow operation is larger diffuser pressure losses at the higher flow netos.

Currently, there is an englne system requirememt of 7515 psia PBP discharge pressure at the Phase II MCC $109 \%$ power level. This requiremert is occesionaly violated with the current design and requires analygle of the pressure drop in the probumor valves bofore the turbopump is accepted. Since a singlecomponent (diffuser only) deslon change minimizes the cos to implement the design change, the redesigned diffusers were tested to quantify the impact of the redesion on the ongine system.

\section{Alr Tent Approsech}

Alr testing was selected as a method of validating the redesioned ditfusers performance with respect to the stall point and pressure rise at Phase II MCC 100\% power level, The current ditfluser and the redeslgned diftusers wore labricated using rapid prolotypling ho order to reduce fabrication ime and lower testing cost." These diffuser were tested using a motal volute and impoller. The alr test resuks corilmed that diffuser redesigns $\$ 1$ and $\$ 2$ shitiod 4 . They also showed that the pressure at the Phace It MCC 109\% power level decreased (Floure 11).

\section{Modilled Impelle:- Dlftuser Dhesion}

Based on the test data, the redesloned diffusers required changing the engine system requirements. Therelore, altemative designs wore evaluated. Obtaining the same PBP discharge pressure as the baseline dosion required increasing the impoller tip dameter and designing a third diffuser (a two-component change).

The gap between the impeller dlscharge and the dituser inlet acts as a mixing zone for the impoller blade wakes. This mixing can significantly suppress pressure-perturbation ofiocts caused by passage of the impoller past the stationary diffuser vanes. The diffuser leading edge radlal location was determined to malntaln the dynamle pressure environment and achieve the pressure ise of the currerit impellar/diffuser. The performanoe oode doterminod that a 0.125 "Increase in diffuser inside diametor and $0.145^{\prime \prime}$ Increase in impeller diameter would achlove the cument impeller/dtffuser discharge pressure at the Phase II MCC 109\% power lovel (Figure 12).

By using rapid prototyping, a polycarbionate ring was manufactured and epoxled to the baseline impeller providing an innovative, low cost mothod of incroasing the Impoller diameter. Agaln, the rosultino dosion has a blunt leading edge and an increased blade thicknesis distribution compared to the baseline diffuser 
(Floure 13). Since the diffuser lending edge was padilly increased, the axial length from the inter to the discharge was reduced to achleve the racuired preseure and boundary leyer profile. Table 4 compares the baseline design to the final diffuser redesign configuration.

\begin{tabular}{|c|c|c|}
\hline Perametor & $\begin{array}{c}\text { Beselino } \\
\text { Deslinn }\end{array}$ & $\begin{array}{c}\text { Flnal } \\
\text { Redesign }\end{array}$ \\
\hline 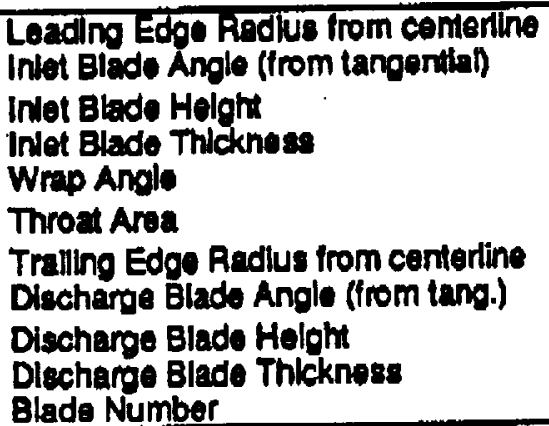 & $\begin{array}{c}2.712^{\circ} \\
9.92^{\circ} \\
0.250^{\circ} \\
0.050^{\circ} \\
52.3^{\circ} \\
0.068 \mathrm{in}^{2} \\
3.41^{\circ} \\
10.8^{\circ} \\
0.346^{\circ} \\
0.100^{\circ} \\
11\end{array}$ & $\begin{array}{c}2.774^{\circ} \\
8.35^{\circ} \\
0.250^{\circ} \\
0.080^{\circ} \\
54.1^{\circ} \\
0.050 \mathrm{in}^{2} \\
3.41^{\circ} \\
10.8^{\circ} \\
0.335^{\circ} \\
0.100^{\circ} \\
11\end{array}$ \\
\hline
\end{tabular}

Table 4 - Prebumer Turbopump Diffuser Aedesigns

The final dituser redesign wth the 5.146" diameter impelier meet all design objectlves (Fioure 14). The impeller dlectiarge llow parameter af which stall ocaure was docreased by $0.008-0.013$ vertus the targeted value of 0.010 and the pressure itse at the Phese If MCC $109 \%$ power level matched the baseline impaller/diffuear deaign. This also demonstrated the centrtugal pump performance program's capability to determine turtopump periormance.

\section{Conclusion}

A total of three difiuser were desloned, analyzed, manuiactured using rapld prototyping and testing in alr. The design requirements of being able to operate the PBP at the 63\% power bvel tor the LTMCC and maintaln the current impeller/diffuser desion pressure rise at the Phase II MCC 109\% power lovel was meot. The dynamle pressure environment for the resulling redesign is not increased from the baseline impeller/dithuser design.

\section{Butarences}

[1] Meng, 8. Y, Jackson, E. D., "The Continuous Diffusion Crossover System Design," Filuid Machinery Spring Conterence, Houston, Taxas, Juno 1883.
[2] McFarland, E. R., "A Rapld Blade-toBlade. Solution for Use in Tubomachinery Design," ASME Paper No. 83-GT-67, March 1983

[3] Crawiord, M. E., Kays, W. M., "STAN5 A Program For Numerlcal Computation of Two-DImonsional internal and External Boundary Layer Flows", NASA CR-2742, Dec. 1976

[4] Lee, O. A., Lundo K. J., Willems R., "Air Tosting of an SSME Tubopump Using Rapid Prototyping," AAIA 94-3152

Furst, R., "Liquld Rocket Engine Centritugal Flow Turbopumps," NASA SP-8100, Dec. 1973 


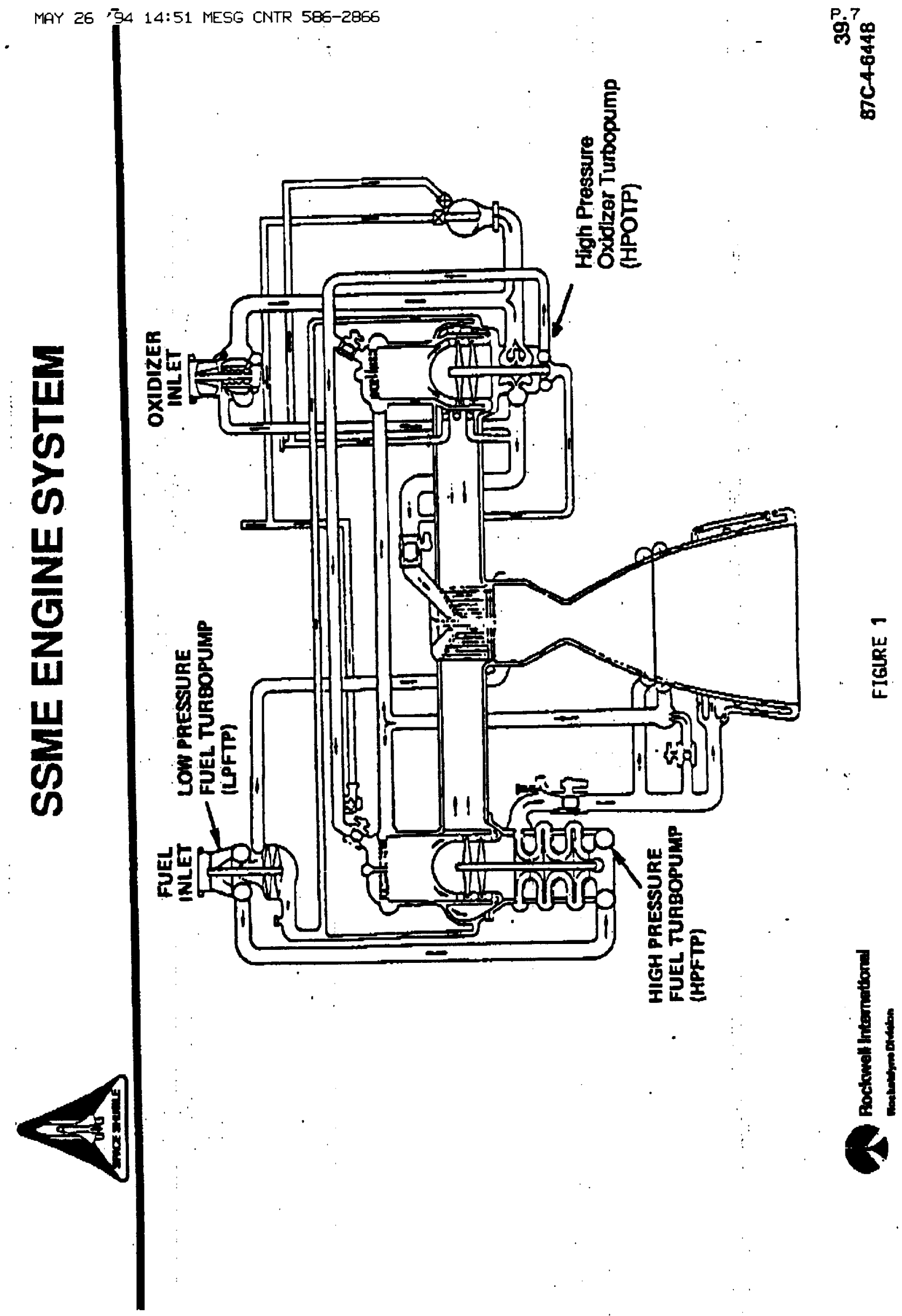



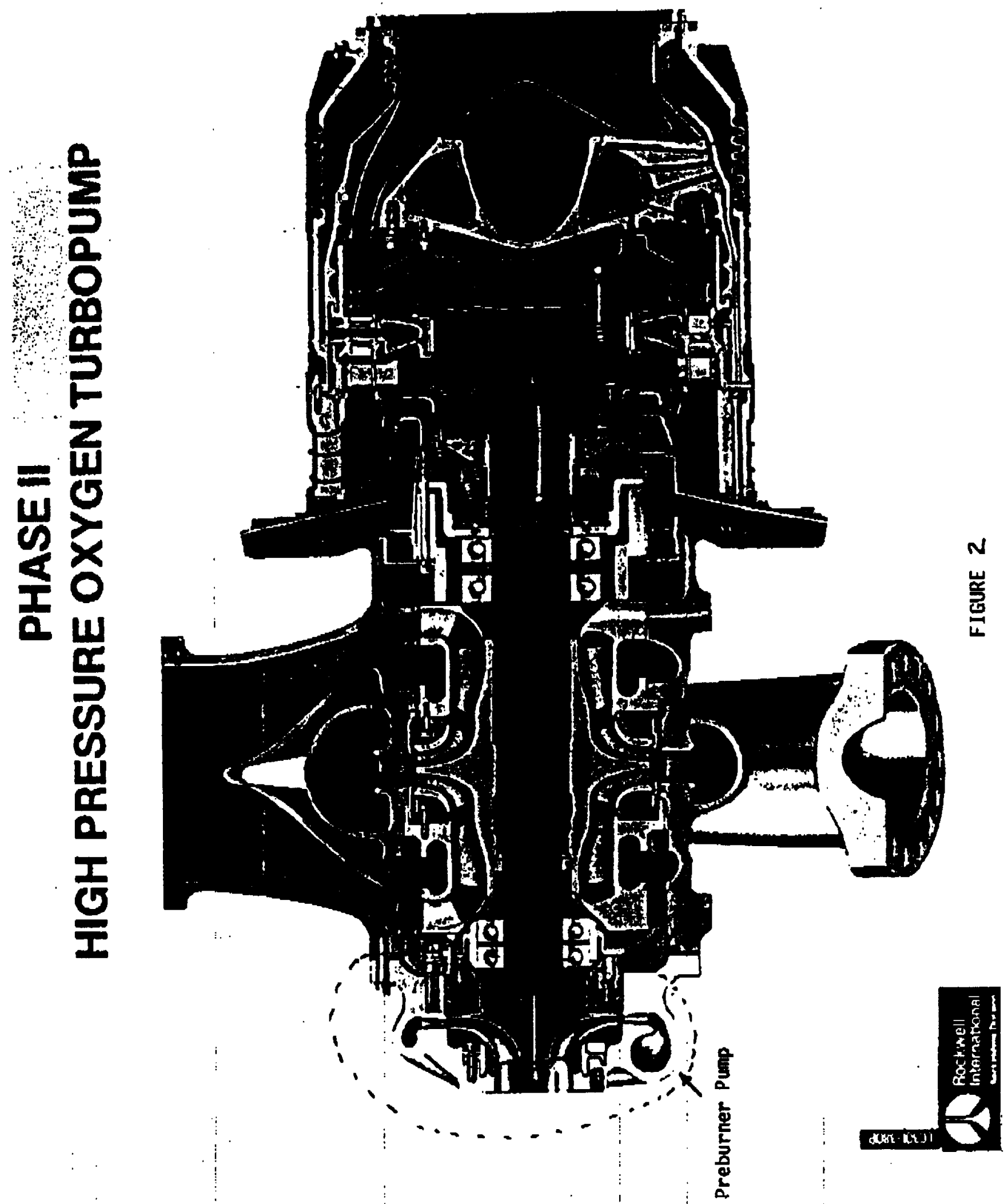


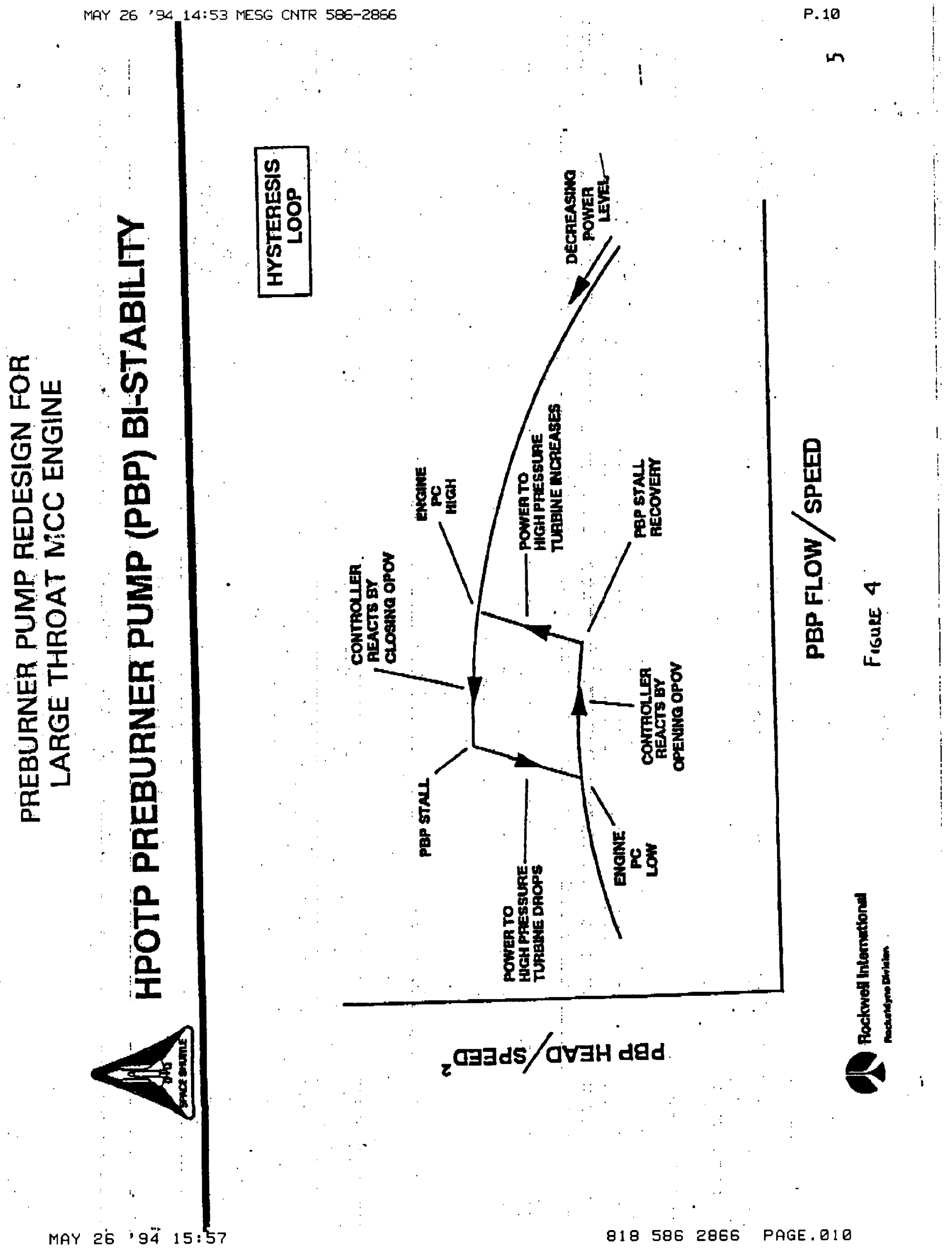




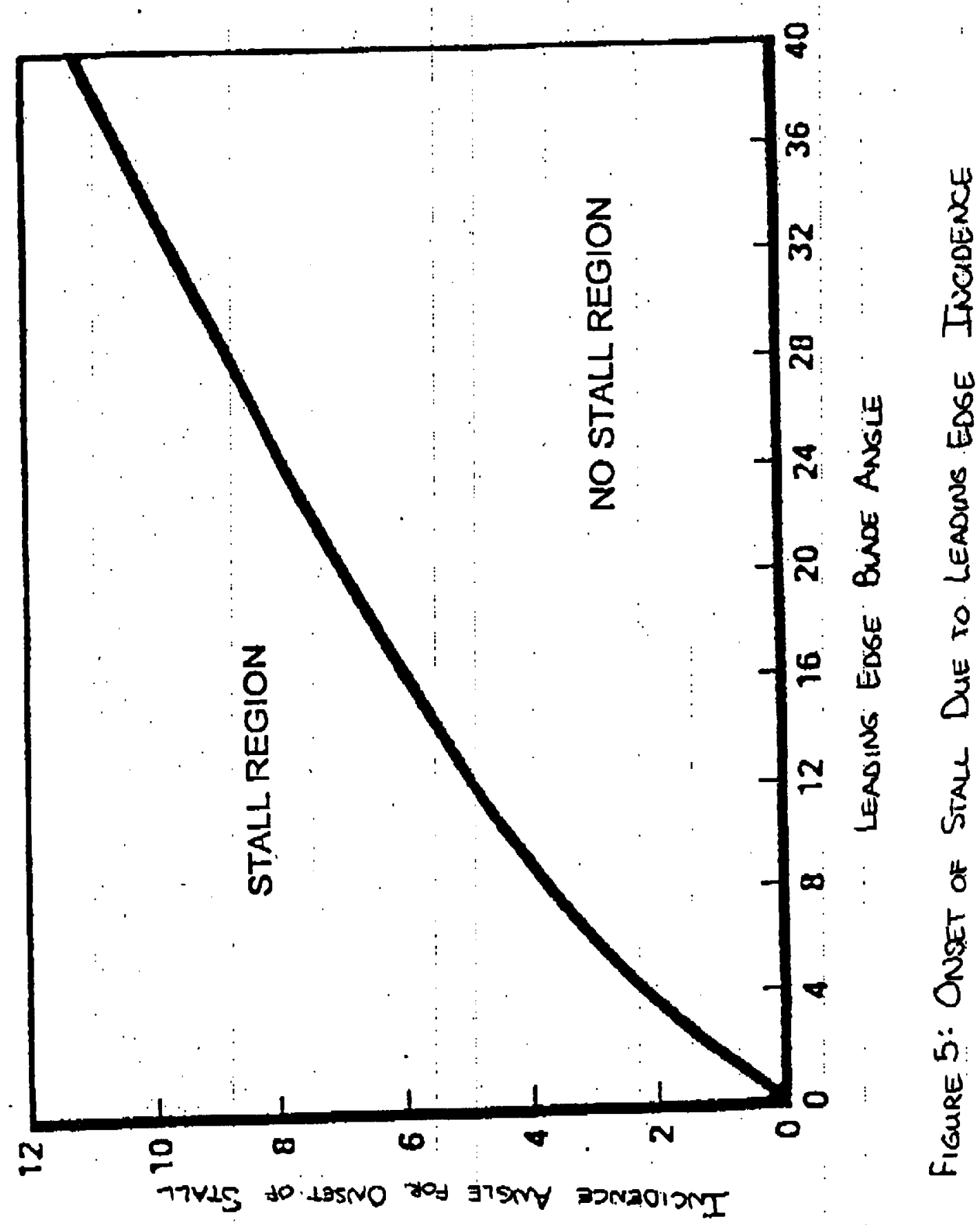




\section{Current Design vs. Redesign \#1}

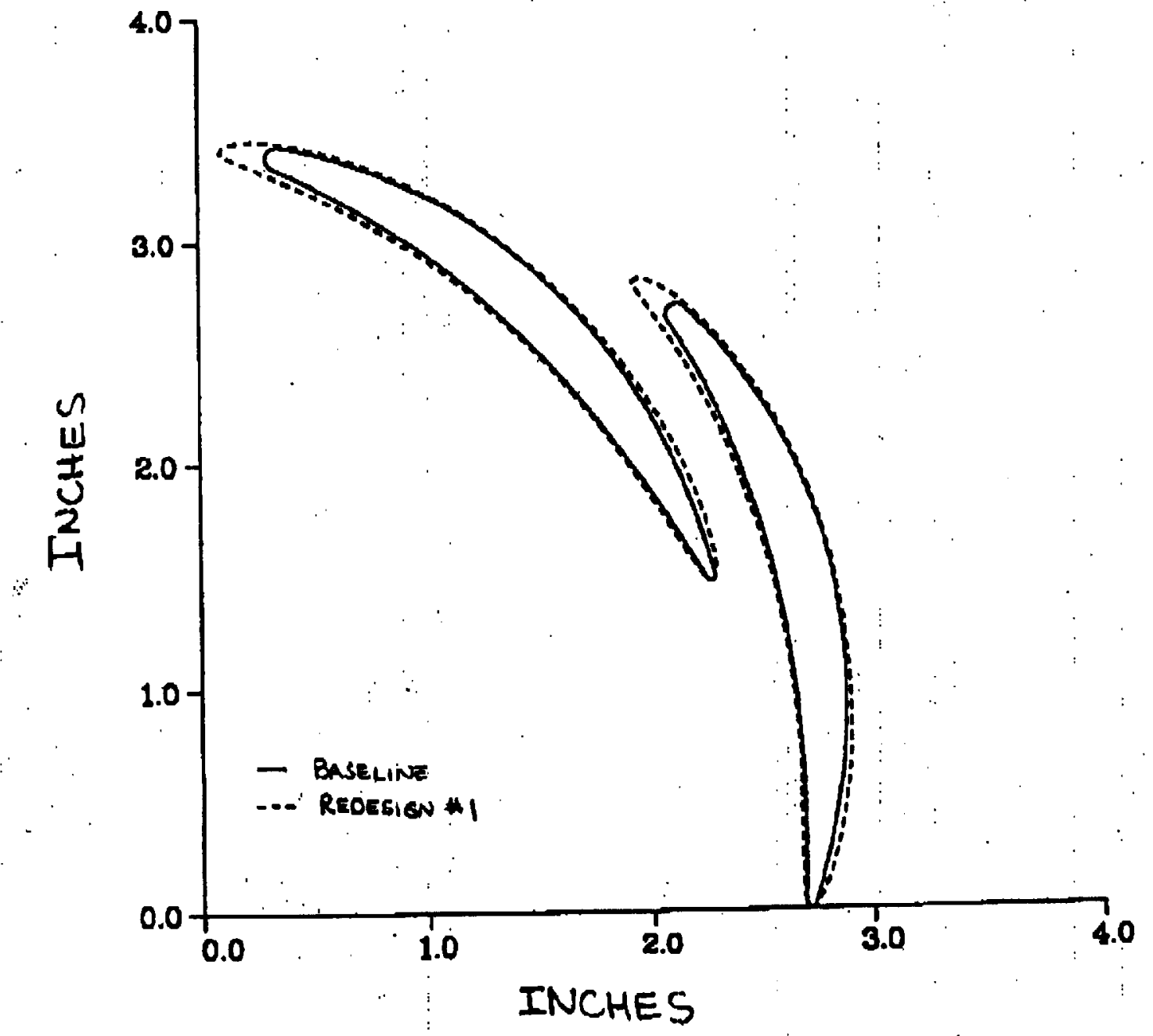

Figure 6: Diffuser Redesign "l GeOMETRY 


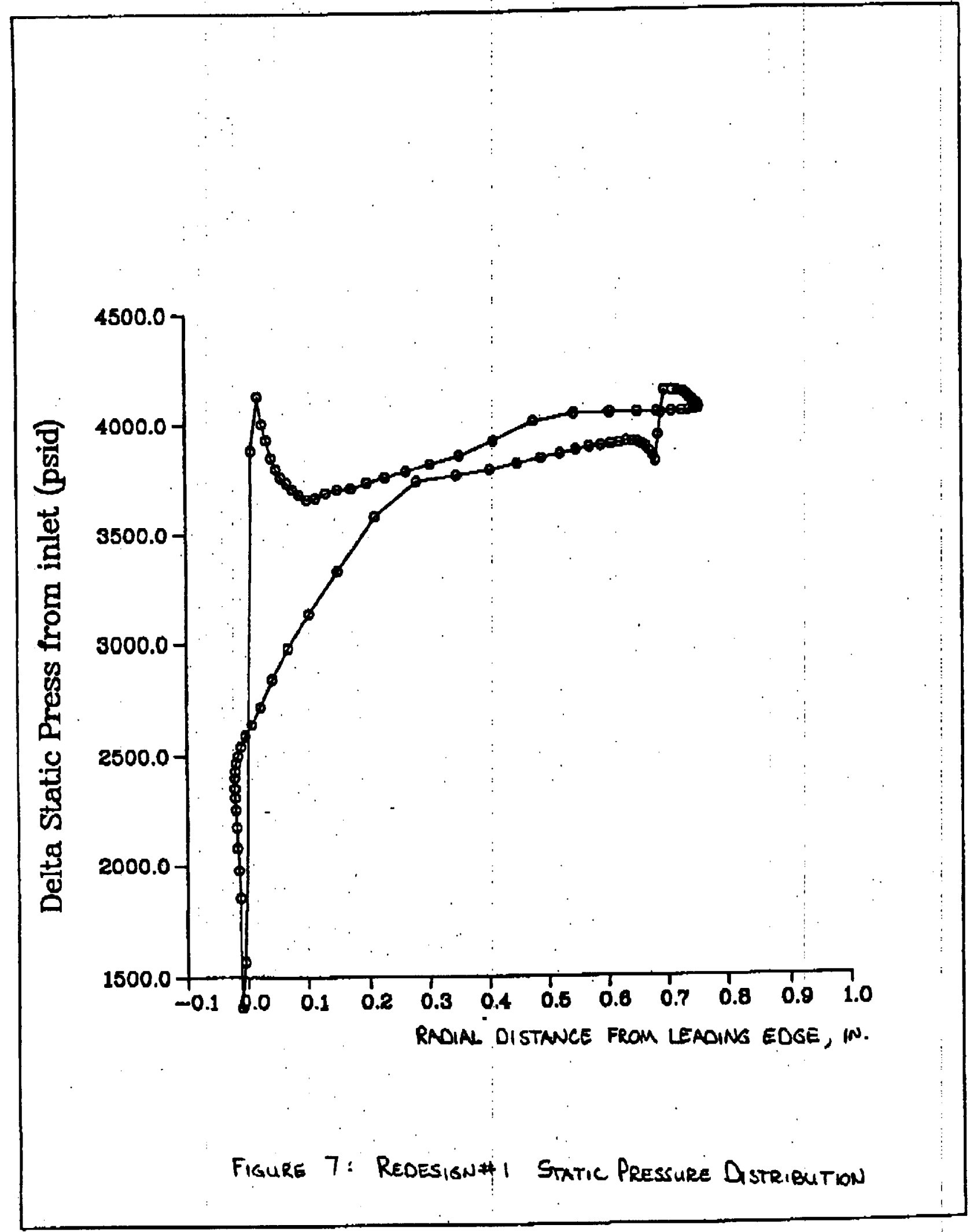




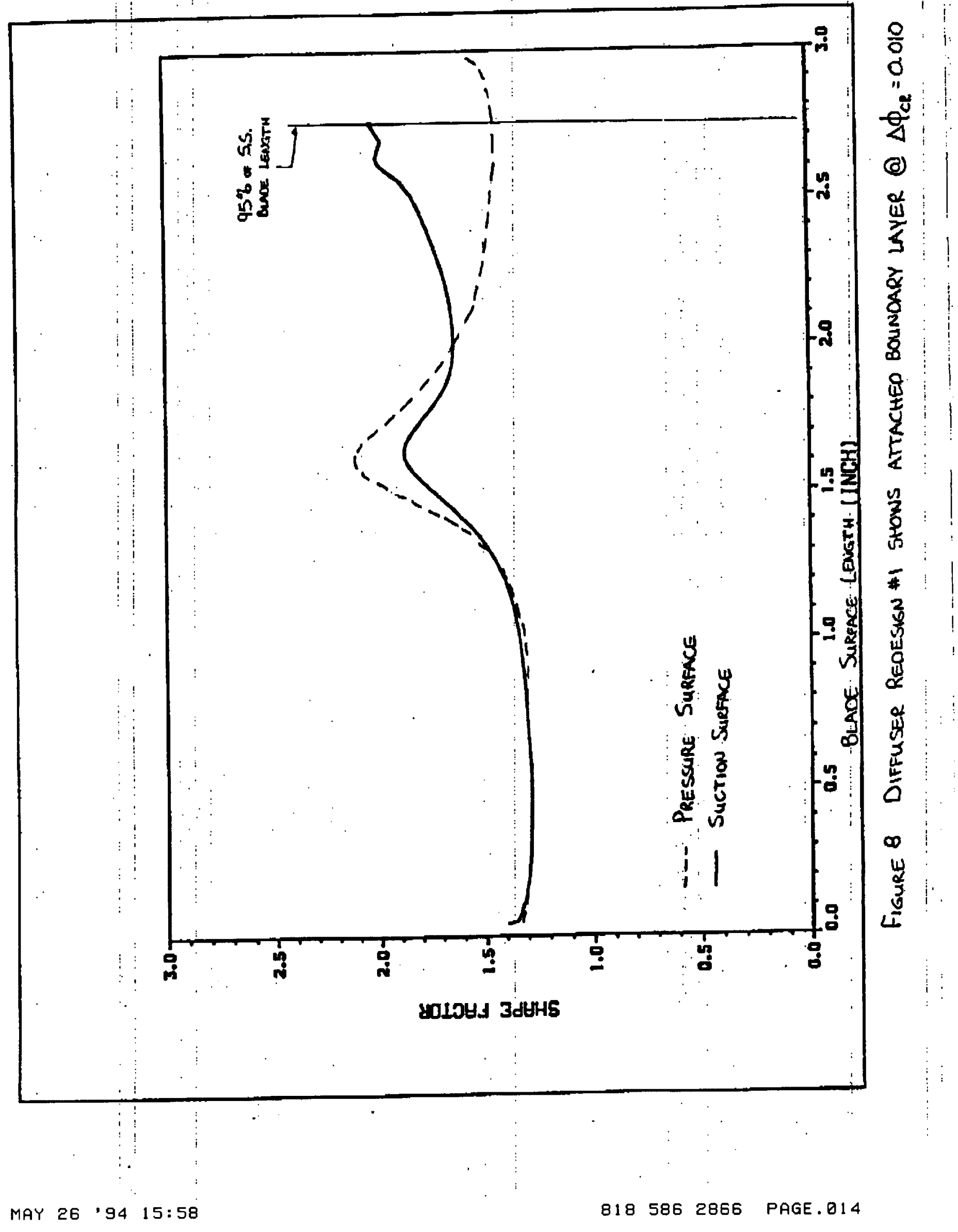




\section{Current Design vs. Redesign \#2}

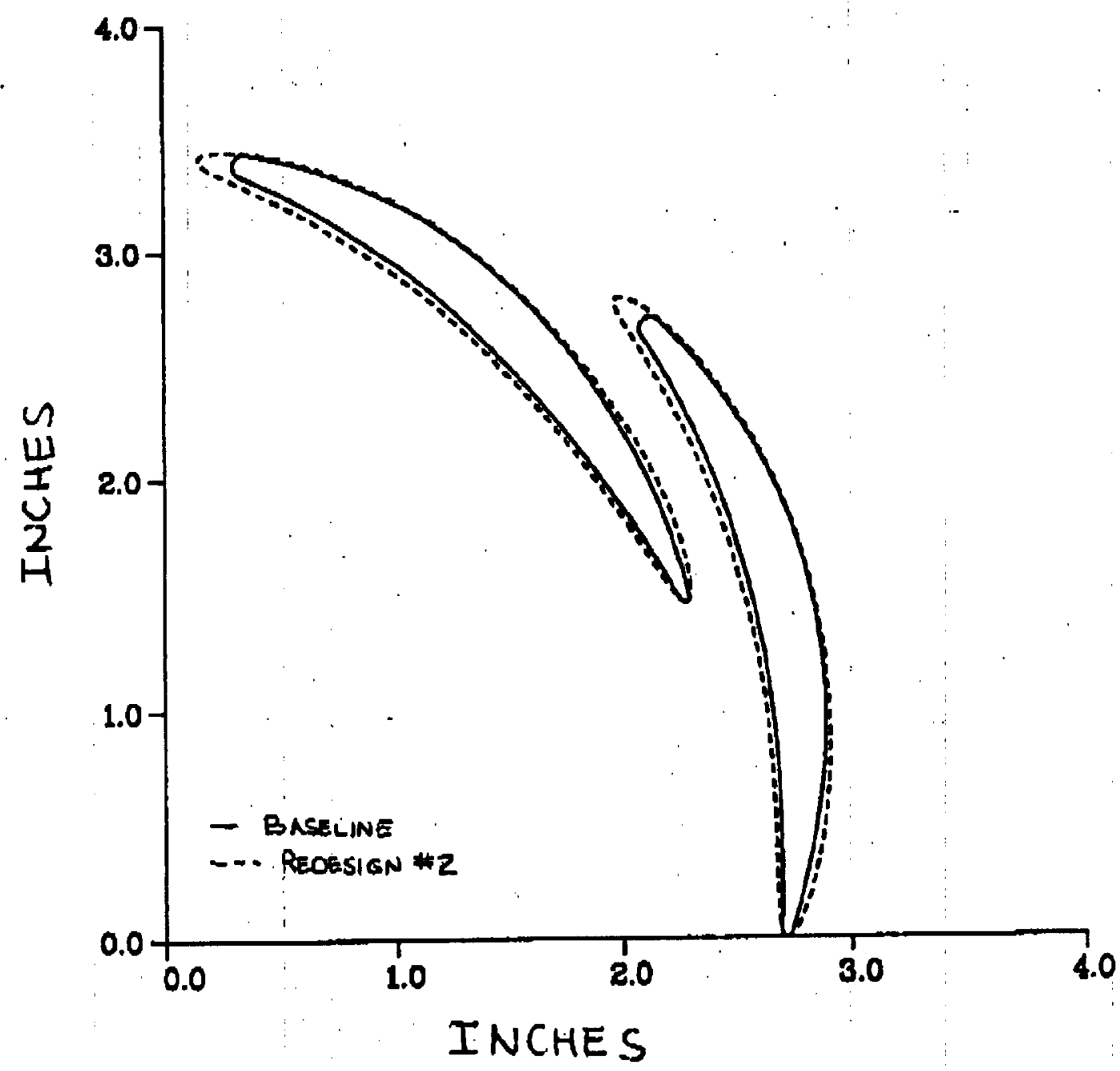

Figure 9: Diffucer redesign: 2 gequetry 


\section{HPOTP PBP Redesign for LTMCC Larger Incidence @ Higher Thrust Level}

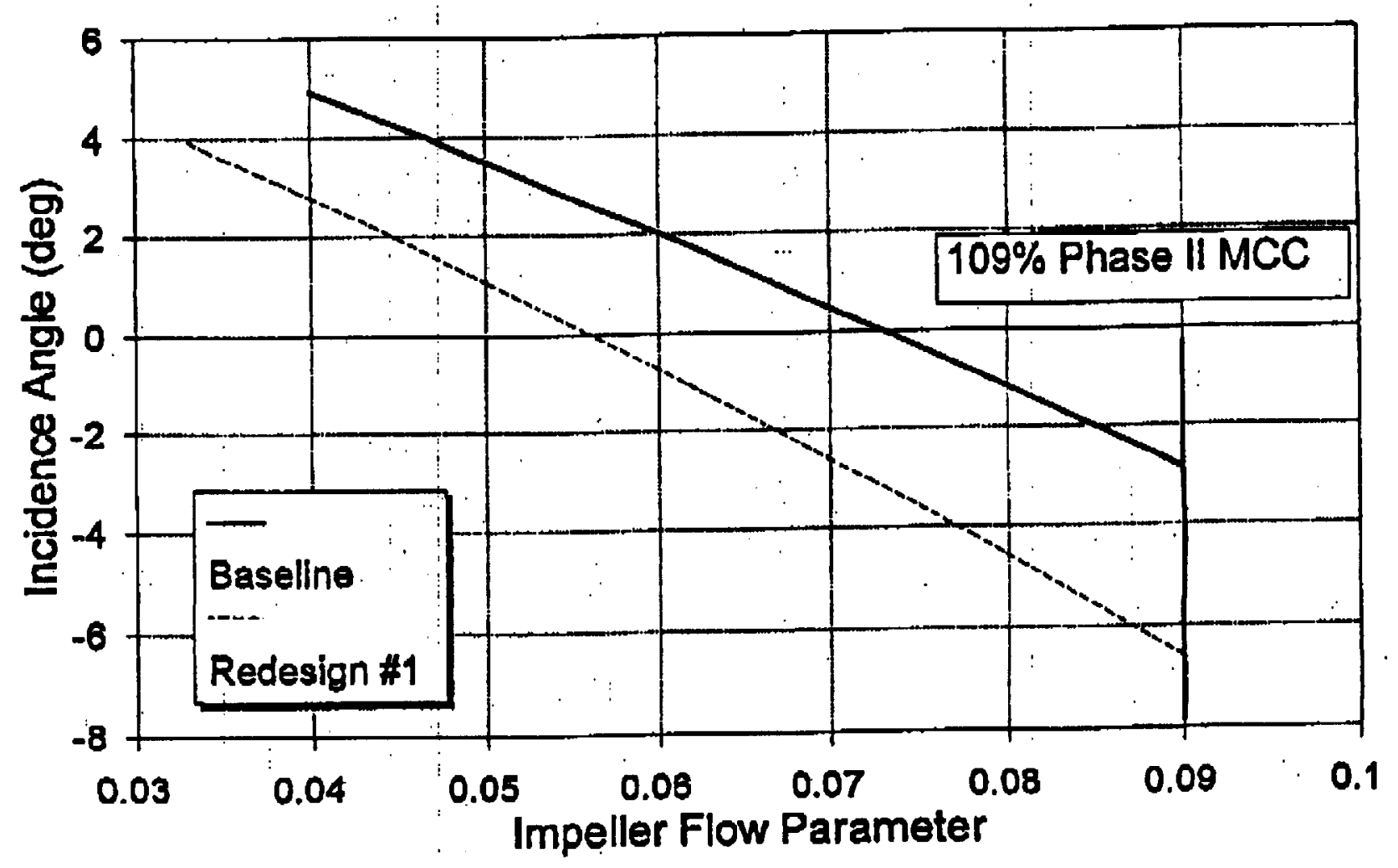

Figure 10 : 


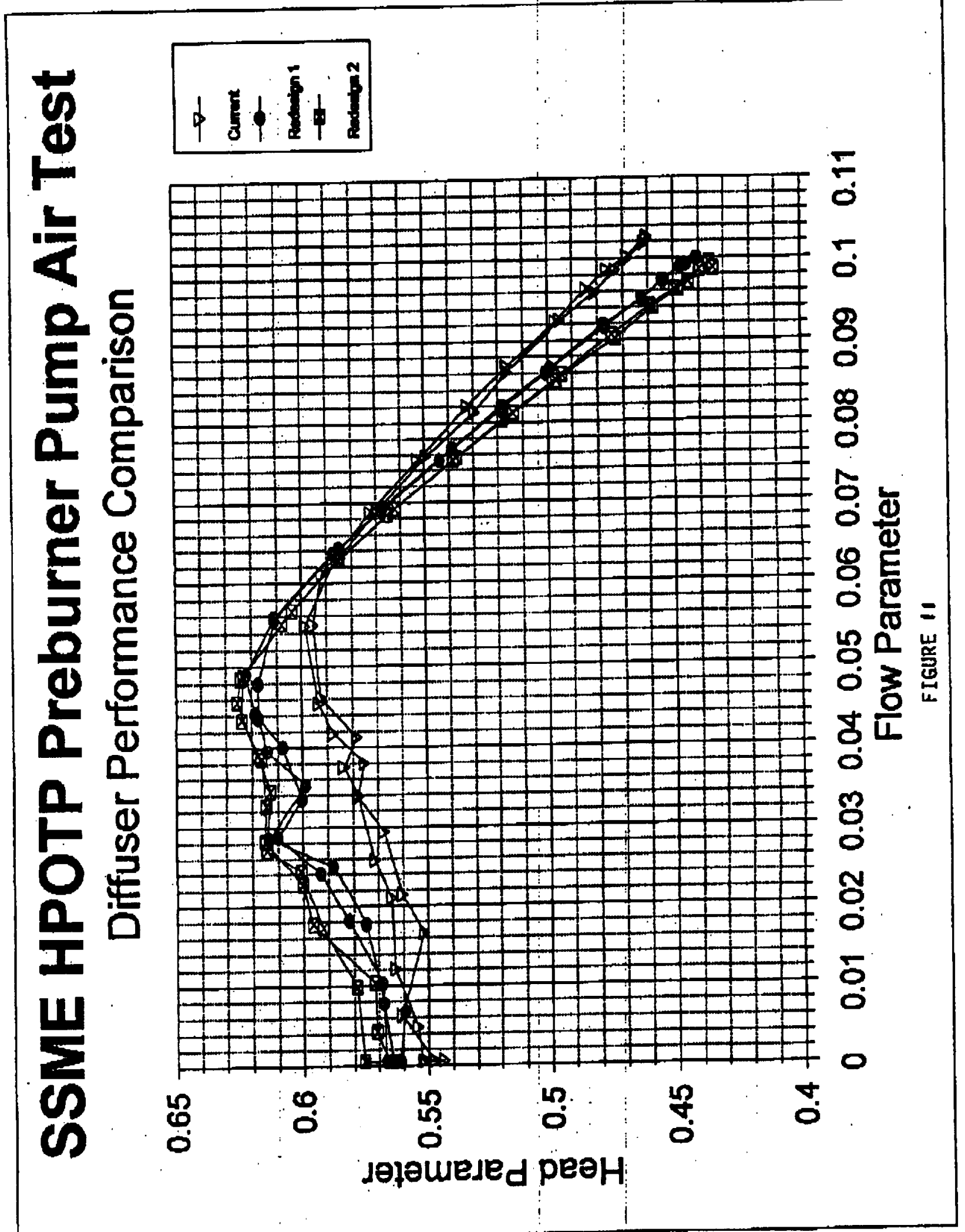




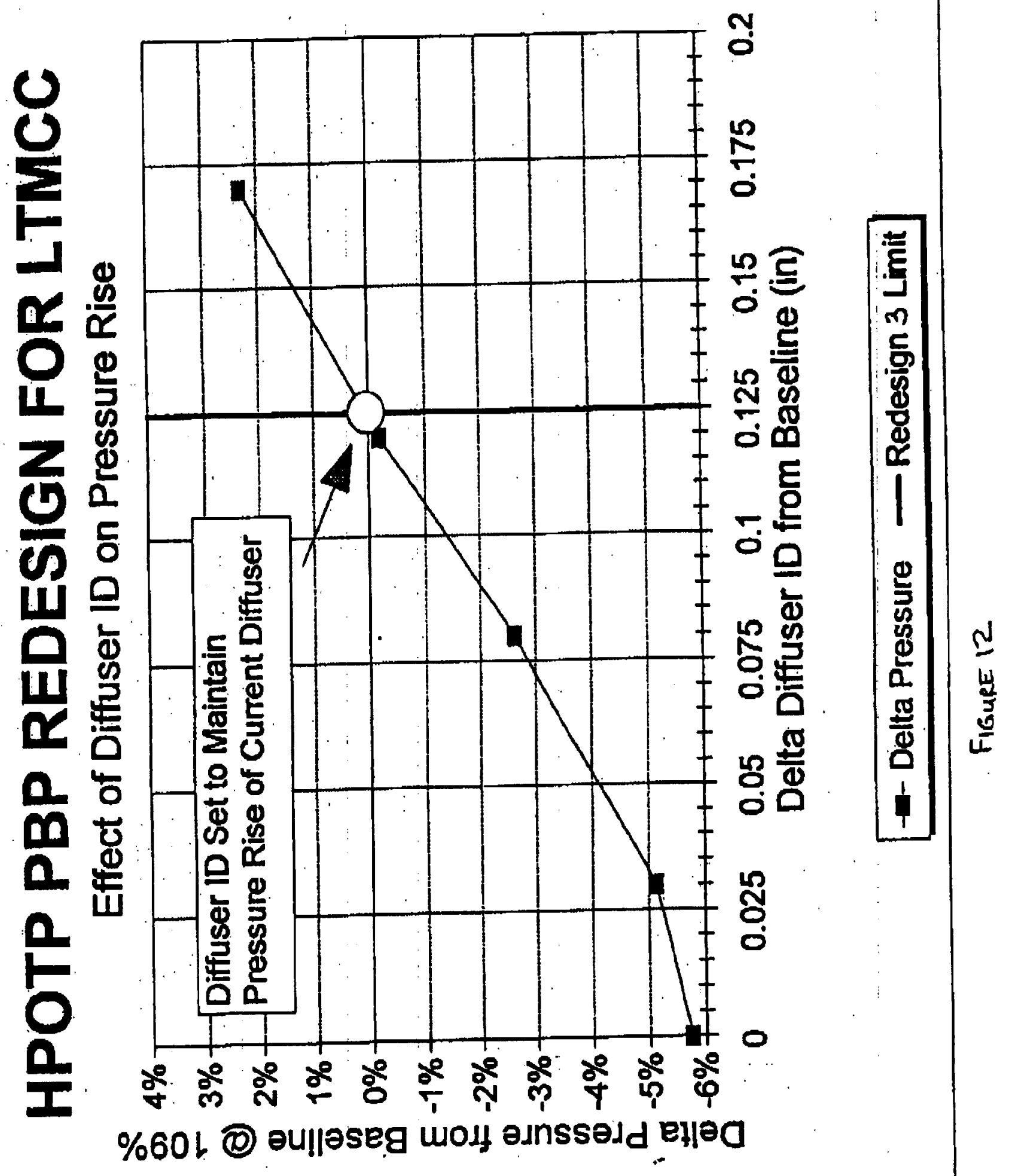




\section{Baseline vs. Redesign \#3}

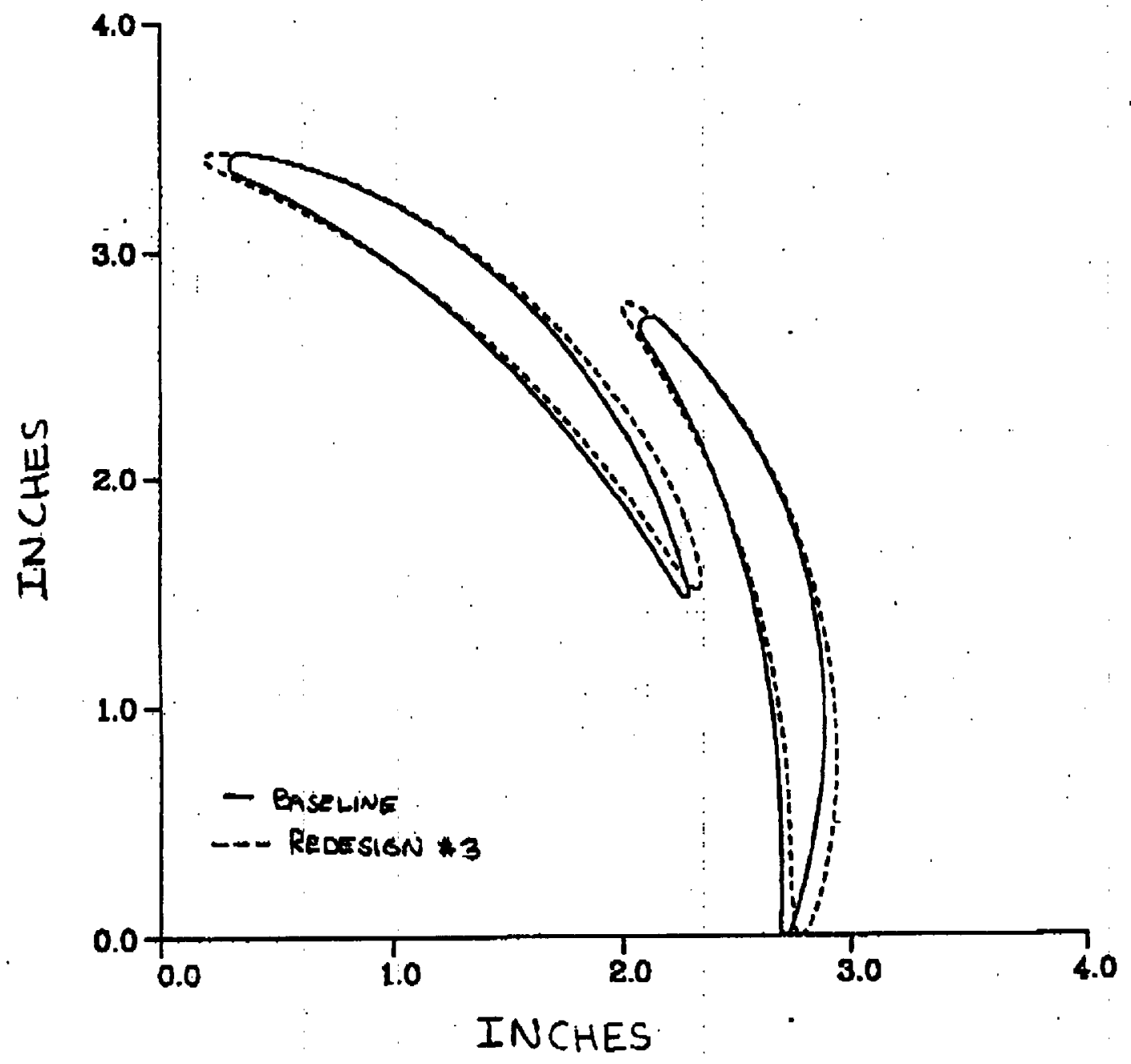

Figure 13: Diffujer Redesign +3 geometry 


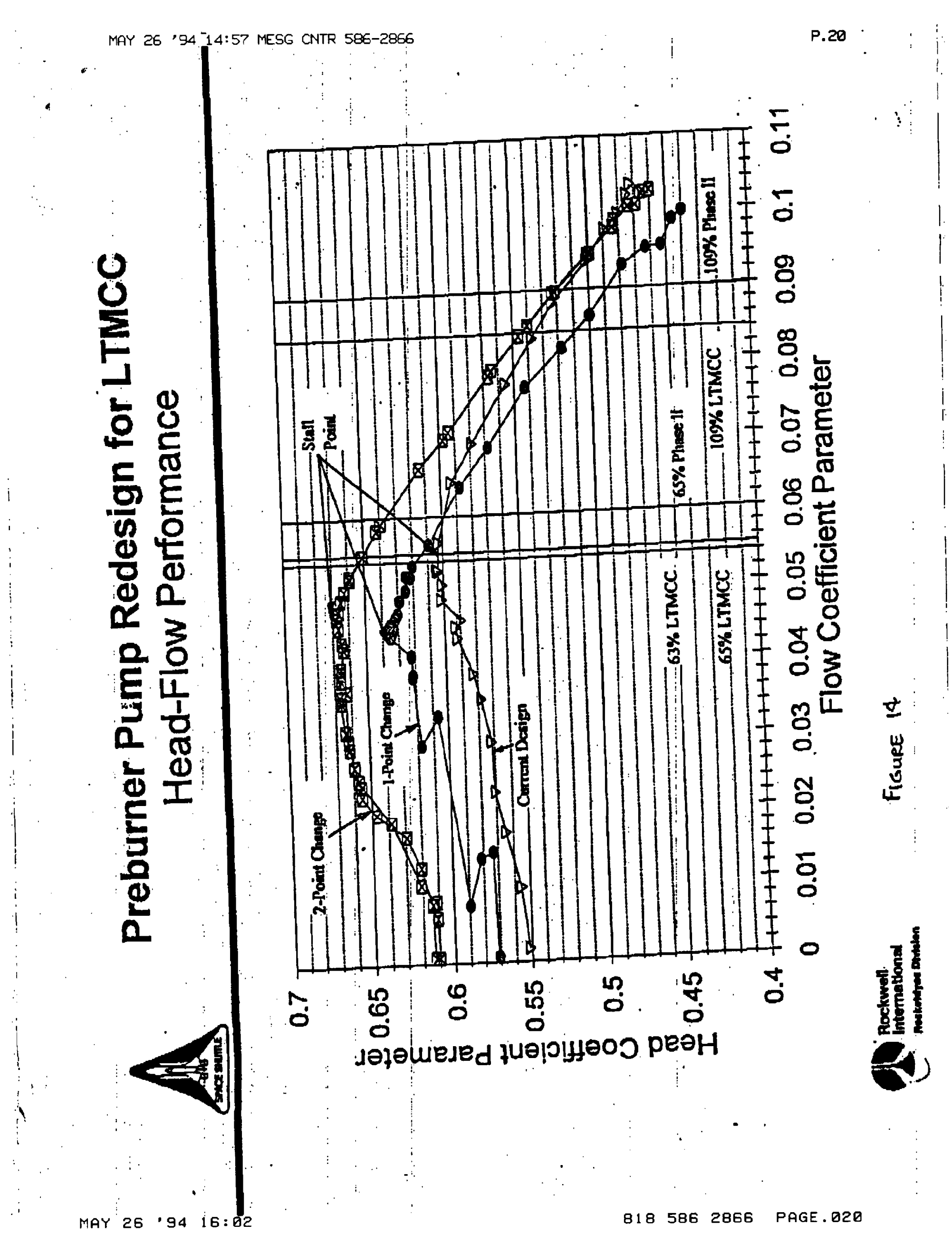

